\title{
Design and Molecular Docking Studies of Quinazoline Derivatives as Antiproliferation
}

Anita Puspa Widiyana*, Galih Satrio Putra, Luthfi Ahmad Muchlashi, Mellany Ika Sulistyowaty \& Tutuk Budiati

Pharmaceutical Chemistry Departement, Faculty of Pharmacy Universitas Airlangga, Surabaya

*Corresponding author: anitapuspawidiyana@gmail.com

\begin{abstract}
Background: Nowadays, a lot of new active substances as anticancer agents have been developed. One of the protein targets of anticancer is selective cyclooxygenase-2 (COX-2). Selective COX-2 is the regulator of cell proliferation. Objective: In this research, quinazoline derivatives were used to design the anticancer agent through a selective COX-2 inhibition. The potential activity of quinazoline derivatives could be increased by substitution in position 2 and 3 of quinazolinone. Molecular docking of selective COX-2 inhibition was required to predict their antiproliferation activity. Methods: The molecular docking of quinazoline derivatives was carried out using Molegro Virtual Docker (MVD) Ver.5.5. Twenty-one of quinazoline derivatives were docked into selective COX-2 with PDB code 3 LN1. The interaction was evaluated based on the re-ranked score comparison between quinazoline derivatives with co-crystallized ligand CEL_682. Celecoxib was used as the reference to this research. Results: The result indicated that 18 of 21 quinazoline derivatives showed the approximately re-ranked score -131.508 to $-108.418 \mathrm{kcal} / \mathrm{mol}$. Eight of these 18 new quinazoline derivatives have re-ranked score better than Celecoxib. Conclusions: In conclusion, 8 of the new quinazoline derivatives are feasible to be synthesize and performed their in vitro evaluation.
\end{abstract}

Keywords: quinazoline derivative, molecular darling, selective COX-2, antipoliferation

\begin{abstract}
Abstrak
Pendahuluan: Saat ini, banyak zat aktif baru sebagai senyawa antikanker telah dikembangkan. Salah satu target protein antikanker adalah siklooksigenase-2 (COX-2) selektif. COX-2 selektif adalah regulator proliferasi sel. Tujuan: Dalam penelitian ini, turunan kuinazolin digunakan untuk merancang senyawa antikanker melalui hambatan COX-2 selektif. Aktivitas dari turunan kuinazolin dapat ditingkatkan dengan penambahan gugus pada posisi 2 dan 3 dari kuinazolinon. Penambatan molekul penghambat COX-2 selektif diperlukan untuk memprediksi aktivitas antiproliferasinya. Metode: Penambatan molekul turunan kuinazolin dilakukan dengan menggunakan Molegro Virtual Docker (MVD) Ver.5.5. Dua puluh satu dari turunan kuinazolin dilakukan penambatan molekul pada COX-2 selektif dengan kode PDB 3LN1. Interaksi dievaluasi berdasarkan perbandingan nilai re-rank antara turunan kuinazolin dengan ko-kristalin ligan CEL_682. Selekoksib digunakan sebagai acuan untuk penelitian ini. Hasil: Hasil penelitian menunjukkan bahwa 18 dari 21 turunan kuinazolin diketahui memiliki nilai re-rank sebesar $-131,508$ sampai -108,418 kkal/mol. Delapan dari 18 turunan kuinazolin yang baru memiliki nilai re-rank yang lebih baik dari Selekoksib. Kesimpulan: 8 dari turunan kuinazolin yang baru pantas untuk disintesis dan dilakukan evaluasi in vitro.
\end{abstract}

Kata kunci: turunan kuinazolin, penambatan molekul, COX-2 selektif, antiproliferasi

\section{INTRODUCTION}

Cancer has caused a major problem in developed as well as undeveloped countries. In 2012, GLOBOCAN, International Agency for Research on Cancer (IARC) reported 14.1 million has been indicated as a new cancer case and 8.2 million people have died due to cancer. Breast cancer was indicated as new higher case than another cancer disease (IARC, 2012). There are many chemotherapeutic strategies for the anticancer treatment that have been proposed and tested in some cases. The 
main procedures of cancer treatment are surgery, irradiation, and chemotherapy. Although the chemotherapeutic management has been conducted and has been showed major advances for patients, the continuous research for new anticancer agent remains important (EL-Azab et al., 2010).

In the field of medicinal chemistry, chemical agents are very important for designing novel agents. One of agents known as a lead compound of anticancer drug is quinazoline (Noolvi \& Patel, 2011). Quinazoline is a fused bicyclic heterocyclic framework which known as benzo-1,3-diazanaphthalene. Numerous compounds of quinazolines have been reported to have biological and pharmacological activities such as antimicrobial, antitumor, antimitotic, anticancer and others (Zayed et al., 2015). In the past, drug development is based on trial and error so it was very expensive and long time. Today, molecular modelling with the aid of computer hardware and software are deducted this risk, the process of discovery is more effective in cost and time (Noolvi \& Patel, 2011).

Maybe synthetized synthesis of quinazolines by adding substituted binding group such as phenyl ring at position 2-, imines at position 3, and chloro in position 7 of quinazoline rings (Noolvi \& Patel, 2013). This substituted was used to increase the activity of cancer cells inhibition. Quinazolines works as anticancer agent through potent inhibition in various enzymes such as epidermal growth factor receptor tyrosine kinase (EGFRTK), dihydrofolate reductase, folate thymidylate synthase, tyrosin kinase, aldose reductase, cyclic GMP phosphodiesterase and DNA repairing enzymes (Zayed $e t$ al., 2015).

The discovery of quinazoline derivatives aimed to design the anticancer agent through cyclooxygenase-2 (COX-2) inhibition. COX-2 is a family of myeloperoxidase located at luminal side of reticulum and nuclear membrane. This enzyme is not detected in most normal tissue, but the increasing of COX-2 enzyme is detected in both premalignant and malignant tissues (Danneberg et al., 2006). Overexpresssion of COX-2 has accelerated biosynthesis of prostaglandin $\mathrm{E}_{2}\left(\mathrm{PGE}_{2}\right)$ which modulates cell proliferation and apoptosis mainly in solid tumors such as colorectal, breast and prostate cancers and more recently, in hematological malignancy (Sobolewski et al., 2009).
This study aims to design and discover new active substances better than previous compounds by using 1 molecular docking. Docking of ligands to the protein of interest followed by scoring to determine the binding affinity and the strength of interaction (Noolvi \& Patel, 2013).

Twenty one of quinazoline derivatives were docked into COX-2 extracted from protein data bank (PDB code 3LN1), by utilizing Molegro Virtual Docker Ver. 5.5 docking software. Quinazolines were docked and scored to identify the ligands that bind similarly to the reference ligand for COX-2 (Celecoxib).

Re-rank score comparison between quinazolines with co-crystalline ligand CEL_682. The potential anticancer activity of quinazolines could be increased by substitution in position 2 and 3 (Noolvi \& Patel, 2013). The substitution position 2 such as 4-nitrophenyl, 2,4-dichlorophenyl and 3,4-dichlorophenyl of quinazolinone. And then, substitution in position 3 such as 3-(substitutedbenzylideneamino) of quinazolinone.

\section{MATERIAL AND METHODS}

\section{Design of new quinazoline derivatives}

The role of the new drug development are (i) determining lead compound, (ii) manipulating the substituent of lead compound (iii) determine the list of new substituents. In this study, quinazoline is a new lead compound of anticancer agent (Noolvi \& Patel, 2011). The Substituents are selected for designing new compound. These substituents are consist of $-\mathrm{NO}_{2}, \mathrm{OCH}_{3}$, $-\mathrm{OH}, \quad-\mathrm{N}\left(\mathrm{CH}_{3}\right)_{2},-\mathrm{Cl}$. They are substituted in benzylideneamino group.

\section{Preparation of target protein $x$-ray structure}

The crystal structure of human COX-2 (PDB ID 3LN1) was selected as the protein target downloaded from http://www.pdb.org/.

\section{Ligands preparation}

The structure of quinazoline derivatives were drawn by using Chem Bio Draw Ultra ver 13.0 (Cambridge Soft). The 2D structure of compounds were converted to the 3D structure utilizing ChemBio 3D 13.0. The optimization molecule and minimization geometry of the ligand were performed using MMFF 94 method and saved as an SYBYL.mol2 format, to be read by Molegro Virtual Docker program. 


\section{Molecular docking studies}

Molecular docking is the computational simulation of a ligand binding to a receptor, which helps to predict binding molecule to the protein target in order to predict the affinity and activity. The study of quinazoline derivatives and cyclooxigenase-2 interaction were evaluated by using molecular docking techniques on Molegro Virtual Docker (MVD) Ver.5.5. (CLC Bio). We used the crystal structure of human COX-2 (code 3LN1, http://www.pdb.org/) as the protein target. Prior to screening the ligands, docking protocol was validated by re-docking 3LN1 ligand into its binding pocket within the COX-2 crystal to obtain the docked pose and RMSD. The protocol is good in reproducing the X-ray crystal structure in complex forms for further docking experiments.

\section{RESULTS AND DISCUSSION}

Virtual screening experiments are the most convenient way to incorporate protein in the docking process by performing docking using an ensemble of static receptor conformations. Molecular docking is used in modern drug design to help understand interaction ligands and receptor. These technique are support to design of novel drug which have specific activity by the mechanism of drug receptor interaction. Computer aided drug design (CAAD) helps to identify small molecules by orienting and scoring them in the active binding site a protein (Elangovan et al., 2013).

The docking simulation technicque was performed by using Molegro Virtual Docker (MVD) Ver.5.5. with quinazoline derivatives and they were docked with cyclooxigenase- 2 as protein target. This program selected the best docked based on two criteria such as ligand binding position and fitness function scores comparison. The parameter to identify the best ligand binding positition was the root-mean square distance (RMSD). The interaction between quinazolines and CEL_682 with COX-2 is shown in Figure 1.

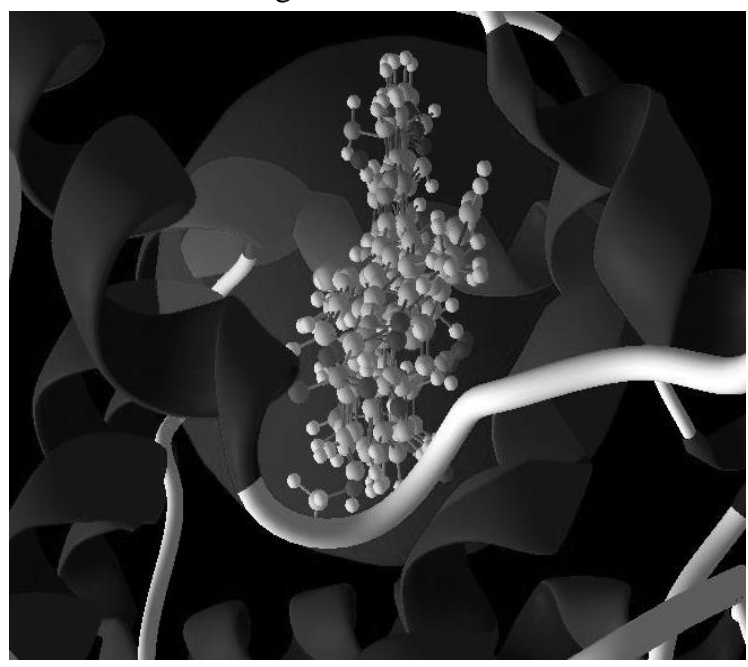

Figure 1. 3D Structure of quinazoline derivatives and CEL_682[A] interact with COX-2

Re-rank score is a value that reflects the binding energy required to form a bond between the ligand and receptor, which predict the activity of compounds. It also causes the bond between the ligand and receptor be more stable. The binding energy value of quinazolines is shown in Table 1. Generally, the obtained eighteen of twenty-one quinazoline derivatives showed the approximate re-rank score -131.508 to $-108.418 \mathrm{kcal} / \mathrm{mol}$. In the Table 2 shows that there are eight quinazoline compounds which value that have greater re-rank score compared to celecoxib. Compound 2 had higher binding energy than other quinazoline derivatives because it has the smallest re-rank score $(-131.508 \mathrm{kcal} / \mathrm{mol})$ but it was not similar with CEL_682[A]. Otherwise, the molecule 1, 15 and 17 from 8 compounds occupied all the three pocket regions and similar binding modes as observed with CEL_682[A]. 
Table 1. Re-rank Score of Quinazoline Derivatives with COX-2

\begin{tabular}{|c|c|c|c|c|}
\hline Serial No. & $\begin{array}{l}\text { Chemical } \\
\text { Structure }\end{array}$ & $\mathbf{R}_{1}$ & $\begin{array}{c}\text { Re-rank } \\
\text { Score }\end{array}$ & $\begin{array}{c}\text { Docked } \\
\text { Pose }\end{array}$ \\
\hline 1 & & $\mathrm{H}$ & -127.35 & $\sqrt{ }$ \\
\hline 2 & & $2-\mathrm{NO}_{2}$ & -131.51 & $\mathrm{x}$ \\
\hline 3 & & $3-\mathrm{NO}_{2}$ & -120.20 & $\mathrm{x}$ \\
\hline 4 & & $4-\mathrm{NO}_{2}$ & -121.90 & $\mathrm{x}$ \\
\hline 5 & & $4-\mathrm{OCH}_{3}$ & -129.56 & $\mathrm{x}$ \\
\hline 6 & & $4-\mathrm{OH}, 3-\mathrm{OCH}_{3}$ & -119.88 & $\sqrt{ }$ \\
\hline 7 & & $4-\mathrm{N}\left(\mathrm{CH}_{3}\right)_{2}$ & 202.41 & $\mathrm{x}$ \\
\hline 8 & & $\mathrm{H}$ & -120.96 & $\sqrt{ }$ \\
\hline 9 & & $2-\mathrm{NO}_{2}$ & -128.41 & $\mathrm{x}$ \\
\hline 10 & & $3-\mathrm{NO}_{2}$ & -121.50 & $\sqrt{ }$ \\
\hline 11 & & $4-\mathrm{NO}_{2}$ & -115.55 & $\mathrm{x}$ \\
\hline 12 & & $4-\mathrm{OCH}_{3}$ & -113.12 & $\mathrm{x}$ \\
\hline 13 & & $4-\mathrm{OH}, 3-\mathrm{OCH}_{3}$ & -117.01 & $\mathrm{x}$ \\
\hline 14 & & $4-\mathrm{N}\left(\mathrm{CH}_{3}\right)_{2}$ & 34.94 & $\mathrm{x}$ \\
\hline 15 & & $\mathrm{H}$ & -121.65 & $\sqrt{ }$ \\
\hline 16 & & $2-\mathrm{NO}_{2}$ & -123.22 & $\mathrm{x}$ \\
\hline 17 & & $3-\mathrm{NO}_{2}$ & -122.56 & $\sqrt{ }$ \\
\hline 18 & & $4-\mathrm{NO}_{2}$ & -108.42 & $\mathrm{x}$ \\
\hline 19 & & $4-\mathrm{OCH}_{3}$ & -113.54 & $\mathrm{x}$ \\
\hline 20 & & $4-\mathrm{OH}, 3-\mathrm{OCH}_{3}$ & -114.14 & $\mathrm{x}$ \\
\hline 21 & & $4-\mathrm{N}\left(\mathrm{CH}_{3}\right)_{2}$ & 131.51 & $\mathrm{x}$ \\
\hline Celecoxib & & & -121.51 & \\
\hline
\end{tabular}

Table 2. Hydrogen Bond Interaction of Quinazoline Derivatives with COX-2

\begin{tabular}{lllc}
\hline Serial. No. & Re-rank Score & Hydrogen bond & $\begin{array}{c}\text { Docked } \\
\text { Pose }\end{array}$ \\
\hline 1 & -127.345 & No $~$ & $\sqrt{ }$ \\
2 & -131.508 & Arg 106, Ser 506, Tyr 341, Tyr 371 & X \\
4 & -121.902 & Arg 106, Tyr 371 41, Tyr 371 & X \\
5 & -129.558 & Ser 516, Tyr 341, Ty 341 & X \\
9 & -128.405 & Arg 106, Tyr 341 & $\sqrt{ }$ \\
15 & -121.651 & Tyr 341 & X \\
16 & -123.224 & Arg 106, Tyr 341 & $\sqrt{ }$ \\
17 & -122.560 & Tyr 341 & \\
Celecoxib & -121.506 & Tyr 371 & \\
\hline
\end{tabular}

The hydrogen bond interaction of 8 compounds from quinazolines is showed in Table 2. Compound 1 has no hydrogen bond interaction with protein residues. The molecules of compound 2,4 and 5 have similar interaction with celecoxib in hydrogen bond with protein residue (Tyr 37). The 4-nitrophenyl ring in position 2 of quinazolinone has similar interaction with Tyr 371 in compound 2 and 5. However different with compund 2, the interaction with Tyr 371 was known in position 4 of benzyledenamino quinazolinone ring. One of them which 
has the lower re-rank score is compound 2. Compound 2 was subtituted 4-nitrophenyl moiety at $\mathrm{C}$-2 and 4-nitrobenzyledeneamino at $\mathrm{N}-3$. This means it has

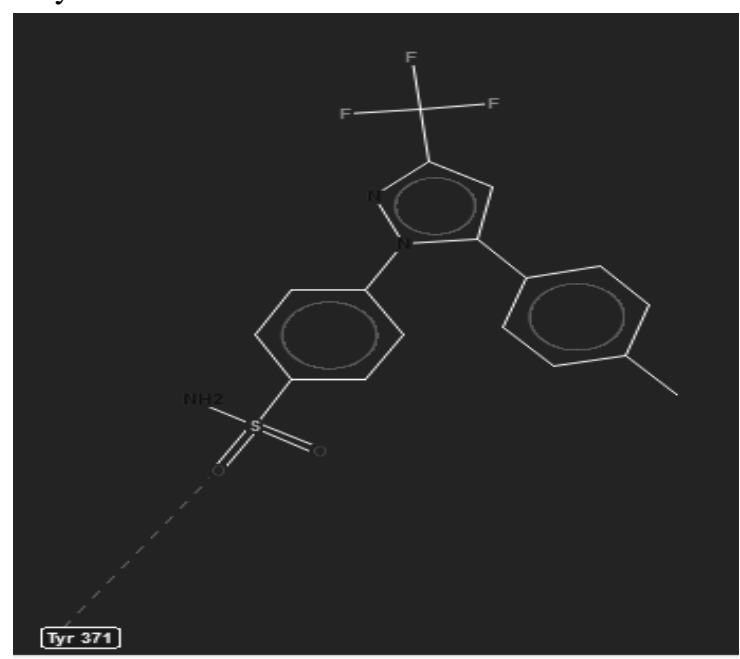

Figure 2. 2D Structure of CEL_682[A] interact

\section{CONCLUSION}

Twenty-one

molecular structure of 2,3-disubstituted-4-3(H)-quinazolinones posssesing, phenyl moiety bound in position 2 and substitutedbenzyledeneamino in position 3 have been docked and score obtained identify the ligands that bind similar orientation as observed with CEL_682 binding for COX-2. The result shows that 2,3-disubstituted-4-3(H)-quinazolinones possessing 4-nitrophenyl moiety at $\mathrm{C}$-2 and 4-nitrobenzyleneamino at N-3 showed lower re-rank score than other quinazolines and celecoxib. It means it has higher binding energy interaction with target receptor. The molecule 1, 15 and 17 were occupied all the three pocket regions and similar binding modes as observed with CEL_682[A]. Therefore, these compounds could be considered as potent COX-2 inhibitor. For further investigation, synthesis and in vitro evaluation are required to get activity against cancer cell.

\section{REFERENCES}

Elangovan, M., Jayaraj, R. 1., Ranjani, V. \& Manigandan, K. (2013). Insilico Docking Studies To Identify Potent Inhibitors Of Alpha-Synuclein Aggregation In Parkinson Disease. Asian J Pharm Clin Res; 6(4); 127-131.

El-Azab, A. S., Al-Omar, M. A., Abdel-Aziz, A. A. M., Abdel-Aziz, N. I., El-Sayed, M. A. A., Aleisa, A. M., Sayed-Ahmed, M. M. \& Abdel-Hamide, S. G. (2010). Design, synthesis and biological evaluation of novel quinazoline derivatives as potential antitumor agents: Molecular docking study. Eur. J. Med. Chem.; 45; 4188-4198. higher binding energy to interact with target receptor. The interaction compound 2 and hydrogen bond is showed in Figure 3 and celecoxib in Figure 2.

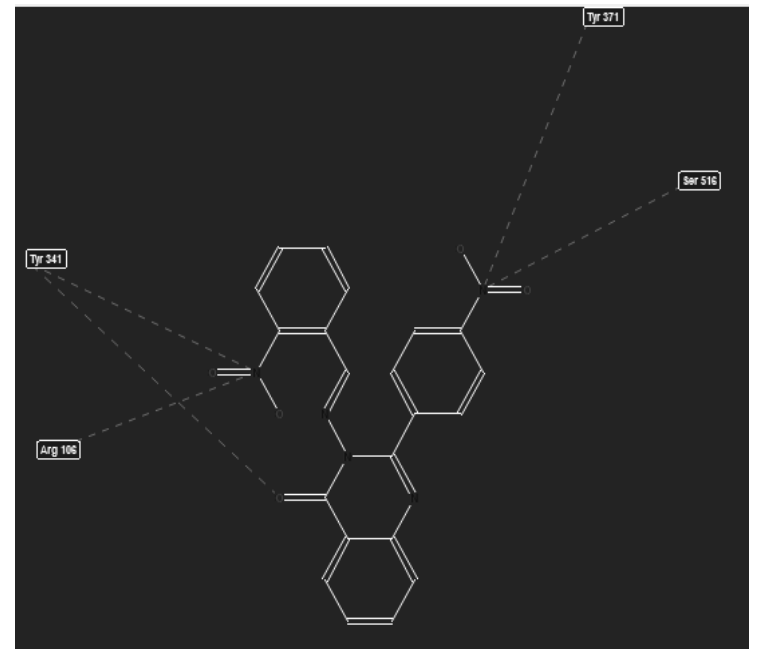

Figure 3. 2D Structure of substance with COX-2 with COX-2

IARC. (2012). GLOBOCAN 2012: Estimated cancer incidence, mortality, and prevalence worldwide in 2012.

http://globocan.iarc.fr/Pages/fact_sheets_populatio n.aspx. Accessed at $16^{\text {th }}$ April 2016

Noolvi, M. N. \& Patel, H. M. (2011). Synthesis and in vitro antitumor activity of substituted quinazoline and quinoxaline derivatives: Search for anticancer agent. Eur. J. Med. Chem.; 46; 2327 - 2346.

Noolvi, M. N. \& Patel H. M. (2013). Synthesis, method optimization, anticancer activity of 2,3,7trisubstitued Quinazoline derivatives and targeting EGFR-tyrosine kinase by rational approach. Arabian Journal of Chemistry; 6; 35-48.

Sobolewski, C., Cerella, C., Dicato, M., Ghibelli, L. \& Diederich, M. (2010). The Role of Cyclooxygenase-2 in Cell Proliferation and Cell Death Human Malignancies. Intr. J. Cell Bio; 121.

Zayed, M. F., Hany, E. A., Saleh, I., Abdell-Sattar, M., Omar \& Adel, S. A. (2015). Synthesis and screening of some new fluorinated quinazolinoneesulphonamide hybrids as anticancer agents. Journal of Taibah University Medical Sciences; 10(3); 333-339. 